\section{Nitrogen Fertigation Concentration and Timing of Application Affect Nitrogen Nutrition, Yield, Firmness, and Color of Apples Grown at High Density}

\author{
Gerry Henry Neilsen ${ }^{1,3}$, Denise Neilsen ${ }^{1}$, and Linda Herbert ${ }^{2}$ \\ Agriculture and Agri-Food Canada, Pacific Agri-Food Research Centre, \\ 4200 Highway 97, Summerland, British Columbia, Canada VOH 1Z0
}

Additional index words. apple cultivars, fruit quality, leaf and fruit N, M.9 rootstock

\begin{abstract}
A randomized complete block, split-plot experiment with six replicates was established and maintained for the first six fruiting seasons (1999 to 2004) in a highdensity apple [Malus sylvestris (L.) Mill var. domestica (Borkh.) Mansf.] orchard on M.9 rootstock planted in Apr. 1998. This report assesses responses to six main-plot fertigation treatments, each containing three tree subplots of five different cultivars (Ambrosia, Cameo, Fuji, Gala, and Silken). Fertigation treatments were a factorial combination of two nitrogen $(\mathrm{N})$ rates and three $\mathrm{N}$ application timings. $\mathrm{N}$ was applied at low $(28 \mathrm{mg} \mathrm{N} / \mathrm{L})$ or high ( $168 \mathrm{mg} \mathrm{N} / \mathrm{L})$ concentrations daily at 0 to 4,4 to 8 , or 8 to 12 weeks after full bloom (wafb). Under greater $\mathrm{N}$ inputs, all cultivars had increased midsummer leaf and harvested fruit $\mathbf{N}$ concentrations, decreased fruit firmness, and in heavy crop years, decreased percent red color. Annual yield of all cultivars was significantly increased by $\mathrm{N}$ rate in a single year, but their cumulative yields were not different between treatments as a result of rate or timing. Altering the timing of $N$ application within 12 wafb only affected leaf and fruit tissue $N$ concentration. Leaf $N$ was higher after 4 weeks of fertigation any time, although concentrations declined over the growing season, reaching minimum values around harvest. Fruit $\mathrm{N}$ was increased by fertigation 4 to 12 wafb. Yield, fruit firmness, and color were unaffected by fertigation timing. Critical fruit quality issues for 'Gala' and 'Silken' were small fruit size, for Ambrosia low fruit numbers, and for 'Cameo' soft fruit. 'Fuji', which achieved high yield and leaf $\mathbf{N}$ concentration and firm fruit, had poor red color regardless of $\mathrm{N}$ treatments.
\end{abstract}

Regulation of $\mathrm{N}$ and water is among the most crucial management decisions for commercial orchard production (Sanchez et al., 1995). Increasingly, strategies have incorporated a need to minimize the unintended loss of $\mathrm{N}$ to the environment (Tagliavini et al., 1996) in reflection of a tendency to overapply $\mathrm{N}$ in many orchards (Weinbaum et al., 1992). The most prominent consequence of excess $\mathrm{N}$ application to agricultural land has been an increase in $\mathrm{N}$ contamination of groundwater and surface water bodies (Wassenaar et al., 2006).

This concern is evident in apple production, in which fertigation has been advocated

\footnotetext{
Received for publication 24 Mar. 2009. Accepted for publication 19 May 2009.

Funding for this research was provided by the Washington Tree Fruit Research Commission and matched by the Agriculture and Agri-Food Canada's Matching Initiative (MII) program.

We thank Judy Braumberger, Brian Drought, David Gregory, Istvan Losso, Andrea Martin, Bill Rabie, and various summer students for technical assistance throughout the project life.

${ }^{1}$ Research Scientists.

${ }^{2}$ Research Technician.

${ }^{3}$ To whom reprint requests should be addressed; e-mail Gerry.Neilsen@agr.gc.ca.
}

$\mathrm{N}$ for supplying the $\mathrm{N}$ requirements of apples in early spring (Malaguti et al., 2001; Millard and Neilsen, 1989; Neilsen et al., 2001a, 2001b), suggesting the possibility that springapplied $\mathrm{N}$ is less efficiently used than $\mathrm{N}$ applied at other times, including late-season foliar $\mathrm{N}$ applications (Cheng et al., 2002). There have been few studies that have investigated the implications of altered fertigation timing on apple tree performance.

For these reasons, an experiment was designed to compare the effects of fertigation solution $\mathrm{N}$ concentration and timing on performance of five different apple cultivars.

\section{Materials and Methods}

In Apr. 1998, five apple [Malus sylvestris (L.) Mill var domestica (Borkh.) Mansf] cultivars (Ambrosia, Cameo, Fuji, Gala, and Silken) on the dwarfing rootstock M.9 were planted in rows separated by $3 \mathrm{~m}$ with $1 \mathrm{~m}$ between trees in each row. In the establishment year, all trees were fertigated with an industry-recommended NP regime involving daily application of calcium nitrate $(15.5 \mathrm{~N}-$ $0 \mathrm{P}-0 \mathrm{~K})$ for 8 weeks after planting, resulting in a cumulative application of $47 \mathrm{~g} \mathrm{~N}$ per tree [British Columbia Ministry of Agriculture and Lands (BCMAL), 2007]. An application of $20 \mathrm{~g}$ phosphorus (P) per tree was also fertigated as ammonium polyphosphate (10N-15P-0K) on 4 June 1998. A randomized complete block, split-plot experimental design was imposed in 1999 and maintained annually until 2004. Eight different fertigation regimes were randomly applied to the main plots within which the five apple cultivars were randomly planted in three-tree subplots. There were six replications. Two border apple trees separated each main plot fertigation treatment within each row and a border row was planted to completely surround the experimental block. Each row comprised 51 trees including three main plot units (45 trees each) and the six guard trees. Eight rows were required for each block with 16 rows required to encompass the six replicate blocks. Two of the fertigation treatments involved the presence or absence of annual $P$ for which results have previously been described (Neilsen et al., 2008). Pertinent to this report was a factorial combination of six fertigation treatments involving two $\mathrm{N}$ rates and three $\mathrm{N}$ timings. $\mathrm{N}$ was applied at low (28 $\mathrm{mg} \mathrm{N} / \mathrm{L})$ or high (168 mg N/L) concentrations daily at 0 to 4,4 to 8 , or 8 to 12 wafb (based on the Ambrosia cultivar) (Table 1). Each fertigation treatment had a separate irrigation line with emitters installed on the appropriate line according to the experimental randomization. To minimize the possibility of other nutrient limitations, $0.17 \mathrm{~g}$ boron (B) per tree per year was fertigated (except 1999 when $0.5 \mathrm{~g} \mathrm{~B} /$ tree was applied) daily 0 to 4 wafb and $\approx 20$ g potassium $(K)$ per tree per year was fertigated daily as potassium chloride $(0 \mathrm{~N}-0 \mathrm{P}-50 \mathrm{~K}) 4$ to 8 wafb. Annual foliar applications of zinc were made according to standard commercial practices (BCMAL, 2007). Each treatment tree was irrigated by 
Table 1. Annual fertigation application date for each fertigation timing and harvest date for each cultivar during fertigation experiment, 1999 to 2004.

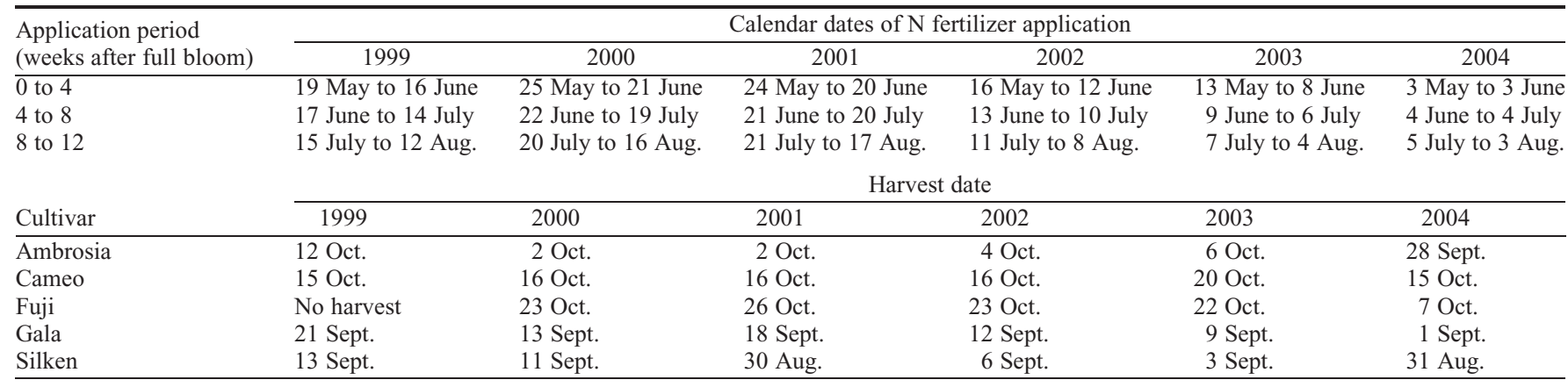

two $4-\mathrm{L} \cdot \mathrm{h}^{-1}$ pressure-compensating emitters (The Toro Company, El Cajun, CA) placed $0.3 \mathrm{~m}$ either side of the tree in the tree row. To minimize water stress, irrigation was applied daily in response to the previous day's evapotranspiration demand automatically scheduled by atmometer (Parchomchuk et al., 1996). A consequence of applying water (and hence dissolved nutrients) according to actual evapotranspiration (ET) is that more water will be applied when ET is higher. Generally this occurred during times 4 to 8 and 8 to 12 wafb when daily temperature was higher (Table 2). There was also a general trend to increase per-tree water application over time because the tree canopy volume and crop coefficient used to express this change also increased over time. Because $\mathrm{N}$ treatments were defined by maintaining $\mathrm{N} / \mathrm{L}$ ) $\mathrm{NO}_{3}-\mathrm{N}$ concentration in the fertigating solution, the amount of $\mathrm{N}$ applied per tree varied within the same treatment according to actual water applications at different times (Table 2). This strategy of $\mathrm{N}$ application by constant $\mathrm{N}$ concentration has previously been reported from Israel (Bar-Yosef et al., 1988). a constant low $\left(28 \mathrm{mg} \cdot \mathrm{L}^{-1}\right)$ or high $(168 \mathrm{mg}$

Nevertheless, there were major differences in the amount of $\mathrm{N}$ applied between low and high $\mathrm{N}$ concentrations regardless of application time.

Trees were trained to a slender spindle system supported by posts and grown in a 2.0-m-wide herbicide strip maintained by annual glyphosate applications. Insect and disease control procedures followed standard commercial recommendations (BCMAL, 2007). Each year, each cultivar was handthinned to the same commercial spacing standard, regardless of cultivar, in June, soon after the cessation of fruit drop.

The experimental site was located on a Skaha loamy sand (Wittneben, 1986), an Aridic Haploxeroll, commonly associated with orchards or vineyards in southern interior British Columbia. Coarse textured soils, including this one, have previously been found susceptible to $\mathrm{N}$ leaching, acidification, and susceptible to the development of $\mathrm{B}$ and $\mathrm{K}$ deficiency under drip fertigation (Neilsen et al., 1995).

Composite samples of 30 leaves from the midportion of extension shoots of the current year's growth were collected from each sub-

Table 2. Average daily temperature, cumulative evapotranspiration (ET), and volume of water and amount of nitrogen (N) applied per tree for each fertigation time, 1999 to 2004.

\begin{tabular}{|c|c|c|c|c|c|c|}
\hline \multirow[b]{2}{*}{ Avg temp $\left({ }^{\circ} \mathrm{C}\right)$} & \multicolumn{6}{|c|}{ Year } \\
\hline & 1999 & 2000 & 2001 & 2002 & 2003 & 2004 \\
\hline 0 to 4 weeks after full bloom (wafb) & 16.2 & 15.3 & 15.7 & 15.7 & 16.6 & 14.2 \\
\hline 4 to 8 wafb & 17.3 & 20.0 & 20.6 & 20.1 & 19.5 & 19.6 \\
\hline 8 to $12 \mathrm{wafb}$ & 21.3 & 22.5 & 21.5 & 22.3 & 25.7 & 23.2 \\
\hline \multicolumn{7}{|l|}{ Cumulative ET (mm) } \\
\hline 0 to 4 wafb & 155 & $64^{\mathrm{z}}$ & 132 & 159 & 144 & 110 \\
\hline 4 to $8 \mathrm{wafb}$ & 146 & 184 & 189 & 171 & 161 & 148 \\
\hline 8 to $12 \mathrm{wafb}$ & 192 & 187 & 158 & 192 & 214 & 180 \\
\hline \multicolumn{7}{|l|}{ Water applied (L/tree) } \\
\hline 0 to $4 \mathrm{wafb}$ & 122 & $52^{z}$ & 159 & 318 & 348 & 229 \\
\hline 4 to 8 wafb & 117 & 139 & 269 & 322 & 410 & 344 \\
\hline 8 to $12 \mathrm{wafb}$ & 152 & 173 & 251 & 423 & 647 & 504 \\
\hline \multicolumn{7}{|l|}{$\mathrm{N}$ applied (g/tree) } \\
\hline \multicolumn{7}{|l|}{ Low N } \\
\hline 0 to $4 \mathrm{wafb}$ & $12.6^{\mathrm{y}}$ & 2.8 & 4.7 & 5.9 & 6.4 & 3.8 \\
\hline 4 to $8 \mathrm{wafb}$ & 6.7 & 3.5 & 7.7 & 11.1 & 10.5 & 10.9 \\
\hline 8 to 12 wafb & 5.6 & 2.8 & 5.1 & 10.0 & 10.9 & 6.1 \\
\hline \multicolumn{7}{|l|}{ High $\mathrm{N}$} \\
\hline 0 to $4 \mathrm{wafb}$ & $52.4^{\mathrm{y}}$ & 17.3 & 37.6 & 38.5 & 27.8 & 20.1 \\
\hline 4 to 8 wafb & 34.3 & 30.4 & 36.6 & 58.2 & 54.5 & 48.5 \\
\hline 8 to $12 \mathrm{wafb}$ & 38.4 & 14.0 & 29.8 & 54.8 & 53.5 & 36.8 \\
\hline
\end{tabular}

${ }^{\mathrm{z}}$ Atmometer malfunction in Spring 2000 resulted in underestimate of ET and water applied during this time period.

${ }^{\mathrm{y}}$ Overapplication of fertigant early in 1999 as a result of unstable suction. plot tree immediately after the cessation of the 4 to 8 wafb fertigation on $15,20,18,11,7$, and 5 July 1999 to 2004, respectively. For the Fuji cultivar, similar composite leaf samples were collected annually after the 0 to 4 and 8 to $12 \mathrm{wafb}$ fertigations (Table 1) and also late in the growing season on 29 Oct. 2003, at harvest ( 7 Oct.), and the first week of November in 2004. All samples were ovendried at $65^{\circ} \mathrm{C}$ and ground in a stainless steel mill. From 1999 to 2001, a 250-mg subsample was digested for $0.75 \mathrm{~h}$ on a block digester at $350{ }^{\circ} \mathrm{C}$ in a $\mathrm{H}_{2} \mathrm{SO}_{4}$ solution containing $\mathrm{K}_{2} \mathrm{SO}_{4}$ and $\mathrm{HgO}$. Nitrogen in the digest was determined through the formation of an ammonium-salicylate complex (Technicon Autoanalyzer II Industrial Method No. 334-74 A/A; Technicon, Elmsford, NY). From 2002 to 2004, leaf N was determined using the LECO FP-528 (Leco Corporation, St. Joseph, MI) combustion analyzer (Sweeney and Rexroad, 1987).

The number and weight of harvested fruit were measured each year at commercial harvest for each cultivar (Table 1) for each treatment and replicate. Harvest date was determined by starch degradation charts developed by local packinghouses for each cultivar. Frost damage to the early bloom in Spring 2003 resulted in much reduced harvested yield in 2003. A randomly selected 10apple sample from the midcanopy location for each experimental plot was also evaluated annually for flesh firmness, skin red color, titratable acidity (TA), and soluble solids concentration (SSC). Flesh firmness was determined with a Baullaf (Lake City Technical Products Ltd., Kelowna, BC, Canada) penetrometer (11.1-mm diameter tip). Percent red skin color (except for the yellow-skinned cultivar Silken) was estimated visually to the nearest $5 \%$. SSC of the juice was measured with a refractometer and TA was determined by titration of juice with $0.1 \mathrm{M} \mathrm{NaOH}$ to an $8.1 \mathrm{pH}$ end point. Juice was obtained from a mechanical juicer, which macerated sectors taken from each apple in the 10-fruit subsample. An additional random sample of 25 fruit was selected annually at harvest from each treatment, cultivar, and replicate for $\mathrm{N}$ analyses. Samples were rinsed under running, distilled water and then air-dried. Chemical analysis was conducted on a composite of opposite, unpeeled quarters from each apple minus stem tissue and seeds. The method of 
fruit $\mathrm{N}$ determination paralleled that of leaf samples. From 1999 to 2001, fruit tissues, previously described, were blended with 1.5 times their weight of distilled water. A 150$\mathrm{mL}$ subsample was further homogenized with a high-speed tissue homogenizer. A weighed 9-mL subsample of homogenized slurry was digested in $5.4 \mathrm{~mL}$ of concentrated $\mathrm{H}_{2} \mathrm{SO}_{4}$ containing $\mathrm{Na}_{2} \mathrm{SO}_{4}(1.8 \mathrm{~g})$, copper $(0.36 \mathrm{~mL}$ $25 \% \mathrm{CuSO}_{4}$ solution), and selenium (0.67 $\left.\mathrm{g} \cdot \mathrm{L}^{-1}\right)$ at $380{ }^{\circ} \mathrm{C}$ for $1 \mathrm{~h}$. Nitrogen was then determined by colorimetric methods, as described for leaf samples. From 2002 to 2004 , $\mathrm{N}$ was determined on a 0.125 -g subsample of freeze-dried sectors using the described for leaf samples. All N data were expressed on a fresh weight (FW) basis.

Analysis of variance was performed on leaf and fruit nutrients, yield, and fruit quality characteristics according to the experimental design (SAS, 1989). Data were analyzed as a split plot with six replicates and a factorial combination of six main plot treatments (two $\mathrm{N}$ rates and three times of $\mathrm{N}$ fertigation). Subplots were three-tree plots of each of five different cultivars. Percent red color was arcsine-transformed before variance analyses. Data were analyzed separately by year as primarily vegetative to fruiting growth during the 6-year experimental period.

\section{Results and Discussion}

Leaf nitrogen. Midterminal leaf $\mathrm{N}$ concentration in the middle of the growing season was significantly affected by $\mathrm{N}$ rate, $\mathrm{N}$ timing, and cultivar (Table 3). Leaf $\mathrm{N}$ concentration was consistently higher for the high $\mathrm{N}$ regime, 1999 to 2004 , including all methods and instrumentation previously a result of the transition of the plots from

times during 2001 and 2002, when there was a significant interaction between $\mathrm{N}$ timing and rate. The timing of fertilizer $\mathrm{N}$ application influenced leaf $\mathrm{N}$ concentration with highest concentrations measured, 1999 to 2004, for leaves collected immediately after cessation of the 4 to 8 wafb fertigation treatment (Table 3). Intermediate leaf $\mathrm{N}$ concentrations were measured for trees fertigated with $\mathrm{N} 0$ to $4 \mathrm{wafb}$ with these values exceeding leaf $\mathrm{N}$ concentrations for trees fertigated with $\mathrm{N} 8$ to 12 wafb (from the previous year) in 4 of the 6 years $(2000,2002$, for both low and high N rates; 2001, 2004 at high $\mathrm{N}$ only). Cultivars differed in leaf $\mathrm{N}$ concentrations despite their exposure to a similar range of treatments. For example, 'Fuji' consistently demonstrated high midsummer leaf $\mathrm{N}$ concentrations, whereas 'Cameo' leaf $\mathrm{N}$ was consistently low (Table 3 ).

There was a consistent, annual trend in midterminal leaf $\mathrm{N}$ concentration across treatments as indicated for the high and low rate $\mathrm{N}$ treatments throughout the 1999 to 2004 growing seasons for 'Fuji' (Fig. 1). The effects of N rate were observable, regardless of time of sampling, with differences between high $\mathrm{N}$ and low $\mathrm{N}$ rate statistically significant for most of the 21 sampling dates except for $12 \mathrm{wafb}$ in 1999 and 2000. Regardless of N treatment, the highest annual concentrations were usually observed 4 wafb (with the exception of 2001), whereas lowest annual concentrations were usually observed 12 wafb after the last fertigation of the growing season or at harvest or postharvest in 2003 and 2004 when late leaf samples were collected.

There was a sixfold difference in the concentration to which the roots were exposed in the low $\left(28 \mathrm{mg} \cdot \mathrm{L}^{-1} \mathrm{NO}_{3}-\mathrm{N}\right)$ versus the high $\left(168 \mathrm{mg} \cdot \mathrm{L}^{-1}\right) \mathrm{N}$ treatments. On

Table 3. Midsummer leaf nitrogen $(\mathrm{N})$ concentration as affected by rate and timing of fertigated $\mathrm{N}$ for Ambrosia, Cameo, Fuji, Gala, and Silken apple cultivars, 1999 to 2004.

\begin{tabular}{|c|c|c|c|c|c|c|c|c|c|c|}
\hline \multirow[b]{2}{*}{ Year } & \multicolumn{10}{|c|}{ Leaf $\mathrm{N}$ concn $\left(\mathrm{g} \cdot \mathrm{kg}^{-1}\right.$ dry weight) } \\
\hline & 1999 & 2000 & & 2001 & & 2002 & 2003 & & 2004 & \\
\hline \multicolumn{11}{|l|}{ Factor } \\
\hline $\mathrm{N}$ rate $(\mathrm{R})^{\mathrm{z}}$ & & & $0-4^{y}$ & $4-8$ & $8-12$ & & & $0-4^{y}$ & $4-8$ & $8-12$ \\
\hline Low (L) & 24.2 & 23.5 & 21.4 & 24.8 & 21.1 & 23.7 & 19.6 & 19.8 & 24.2 & 20.0 \\
\hline $\operatorname{High}(\mathrm{H})$ & 25.3 & 25.0 & 24.5 & 26.0 & 22.7 & 26.2 & 22.5 & 24.0 & 26.0 & 21.1 \\
\hline Significance & $*$ & $* * *$ & \multicolumn{3}{|c|}{$\mathrm{SE}^{\mathrm{x}}=0.3$} & $* * *$ & $* * *$ & \multicolumn{3}{|c|}{$\mathrm{SE}=0.3$} \\
\hline \multicolumn{11}{|l|}{$\mathrm{N}$ timing $(\mathrm{T})^{\mathrm{y}}$} \\
\hline 0 to 4 wafb & $24.6 \mathrm{~b}$ & $24.2 \mathrm{~b}$ & & & & $24.1 \mathrm{~b}$ & $19.9 \mathrm{~b}$ & & & \\
\hline 4 to $8 \mathrm{wafb}$ & $25.9 \mathrm{a}$ & $25.3 \mathrm{a}$ & & & & $27.2 \mathrm{a}$ & $24.4 \mathrm{a}$ & & & \\
\hline 8 to 12 wafb & $23.9 \mathrm{~b}$ & $23.2 \mathrm{c}$ & & & & $23.2 \mathrm{c}$ & $18.7 \mathrm{~b}$ & & & \\
\hline Significance & $* *$ & $* * *$ & & & & $* * *$ & $* * *$ & & & \\
\hline $\mathrm{R} \times \mathrm{T}$ interaction & NS & NS & & $*$ & & NS & NS & & $*$ & \\
\hline Cultivar (CV) & & & $0-4^{y}$ & 4-8 & $8-12$ & & & & & \\
\hline Ambrosia & $25.9 \mathrm{a}$ & $25.1 \mathrm{~b}$ & 23.7 & 26.6 & 23.5 & $25.4 \mathrm{ab}$ & $22.3 \mathrm{a}$ & & $20.9 \mathrm{c}$ & \\
\hline Cameo & $23.8 \mathrm{c}$ & $22.9 \mathrm{c}$ & 20.8 & 24.5 & 19.3 & $23.1 \mathrm{c}$ & $18.9 \mathrm{c}$ & & $21.6 \mathrm{c}$ & \\
\hline Fuji & $26.4 \mathrm{a}$ & $26.1 \mathrm{a}$ & 24.5 & 26.6 & 23.4 & $26.2 \mathrm{a}$ & $23.2 \mathrm{a}$ & & $24.2 \mathrm{a}$ & \\
\hline Gala & $22.8 \mathrm{~d}$ & $23.6 \mathrm{c}$ & 23.6 & 23.0 & 23.0 & $24.8 \mathrm{~b}$ & $21.1 \mathrm{~b}$ & & $22.5 \mathrm{~b}$ & \\
\hline Silken & $25.0 \mathrm{~b}$ & $23.5 \mathrm{c}$ & 22.7 & 23.9 & 20.1 & $24.8 \mathrm{~b}$ & $19.5 \mathrm{c}$ & & $22.9 \mathrm{~b}$ & \\
\hline Significance & $* * *$ & $* * *$ & & $\mathrm{SE}=0.4$ & & $* * *$ & $* * *$ & & $* * *$ & \\
\hline $\mathrm{R} \times \mathrm{CV}$ & NS & NS & & NS & & NS & NS & & NS & \\
\hline $\mathrm{T} \times \mathrm{CV}$ & NS & NS & & $* *$ & & NS & NS & & NS & \\
\hline Grand mean & 24.8 & 24.2 & & 23.4 & & 24.8 & 21.0 & & 22.5 & \\
\hline
\end{tabular}

${ }^{\mathrm{z}}$ Fertigated at either $28 \mathrm{mg} \mathrm{N} / \mathrm{L}$ (low) or $168 \mathrm{mg} \mathrm{N} / \mathrm{L}$ (high) as calcium nitrate (15.5N-0P-0K).

${ }^{y}$ Applied weeks after full bloom (wafb) based on bloom date of 'Ambrosia'.

${ }^{x}$ When interaction significant, SE of the interaction indicated.

$*, * *, * * *$ Means significantly different at $P=0.05,0.01,0.001$, respectively, or nonsignificantly (NS) different. average, throughout the study, this resulted in annual applications of $6.6 \mathrm{~g} \mathrm{~N} /$ tree at low $\mathrm{N}$ versus $36.5 \mathrm{~g} \mathrm{~N} /$ tree at high $\mathrm{N}$ (Table 2). At the planting densities used, this resulted in application of $22 \mathrm{~kg} \mathrm{~N} / \mathrm{ha}$ or $122 \mathrm{~kg} \mathrm{~N} / \mathrm{ha}$, respectively. Despite the wide range in $\mathrm{N}$ available to apple roots between the two $\mathrm{N}$ treatments, differences in annual leaf $\mathrm{N}$ concentration between low and high $\mathrm{N}$ rates were modest, ranging between $5 \%$ and $15 \%$. This implies an inefficiency of $\mathrm{N}$ use at the highest $\mathrm{N}$ rate $(168 \mathrm{mg} \mathrm{N} / \mathrm{L})$, consistent with research in Israel indicating that daily fertigation of a $42 \mathrm{mg} \mathrm{N} / \mathrm{L} \mathrm{NO}_{3}-\mathrm{N}$ concentration resulted in most efficient use of $\mathrm{N}$ for 'Golden Delicious' apples grown outdoors in pots (Bar-Yosef et al., 1988). Estimates of annual $\mathrm{N}$ removal in fruit and senescent leaves for 3- to 6-year-old, high-density 'Elstar' or 'Gala' on M.9 rootstock ranged from 30 to $36 \mathrm{~kg} \mathrm{~N} / \mathrm{ha}$ (Neilsen and Neilsen, 2002). Thus, application at a $42 \mathrm{mg} \cdot \mathrm{L}^{-1} \mathrm{NO}_{3}$ $\mathrm{N}$ concentration, like in Israel, which would have supplied $\approx 37.5 \mathrm{~kg} \mathrm{~N} / \mathrm{ha} /$ year, when applied for 4 weeks under our climatic conditions, would have more closely matched annual tree $\mathrm{N}$ requirements than applying a $28 \mathrm{mg} \mathrm{N} / \mathrm{L}$ concentration or a $20 \mathrm{mg} \mathrm{N} / \mathrm{L}$ concentration, as previously recommended for newly planted, primarily vegetative apple trees (Neilsen et al., 2001b).

Leaf $\mathrm{N}$ concentrations at both low and high $\mathrm{N}$ rates consistently achieved the adequate leaf $\mathrm{N}$ concentration range (Fig. 1) between 19 and $24 \mathrm{mg} \cdot \mathrm{kg}^{-1}$ for apple cultivars 8 wafb in midsummer (BCMAL, 2007). It was noteworthy that leaf $\mathrm{N}$ concentrations were also generally adequate for all cultivars despite consistent annual differences in trees receiving the same range of fertigation treatments. Leaf $\mathrm{N}$ concentrations near the lower threshold of $19 \mathrm{mg} \cdot \mathrm{kg}^{-1}$ were rare, like in 2001 for 'Cameo' fertigated 8 to 12 wafb and 'Cameo' and 'Silken' in 2003 (Table 3). The seasonal trends in leaf $\mathrm{N}$ concentration, as illustrated for 'Fuji', indicated that, according to leaf standards, which were developed for midgrowing season, leaf $\mathrm{N}$ concentrations were generally high $4 \mathrm{wafb}$, low 12 wafb, and apparently inadequate when $\mathrm{N}$ withdrawal is underway in Oct. to Nov. 2002 to 2003. However, the significance of these low late-season values is unknown because they occurred for both high and low $\mathrm{N}$ treatments. Furthermore, it was possible to increase leaf $\mathrm{N}$ concentration regardless of the timing of $\mathrm{N}$ application, including within 4 wafb, when some $\mathrm{N}$ is being remobilized from storage (Neilsen and Neilsen, 2002). This provides assurance that leaf $\mathrm{N}$ concentration can be increased by fertigation of $\mathrm{N}$ at any time within 12 wafb should low leaf $\mathrm{N}$ concentrations occur in a planting. The desirability of such applications would depend on other associated effects of altered time of $\mathrm{N}$ application on apple production.

Fruit nitrogen. Fruit $\mathrm{N}$ concentration at harvest was consistently higher at high $\mathrm{N}$ rate, although there was an interaction between cultivar and $\mathrm{N}$ rate in 2000 and 


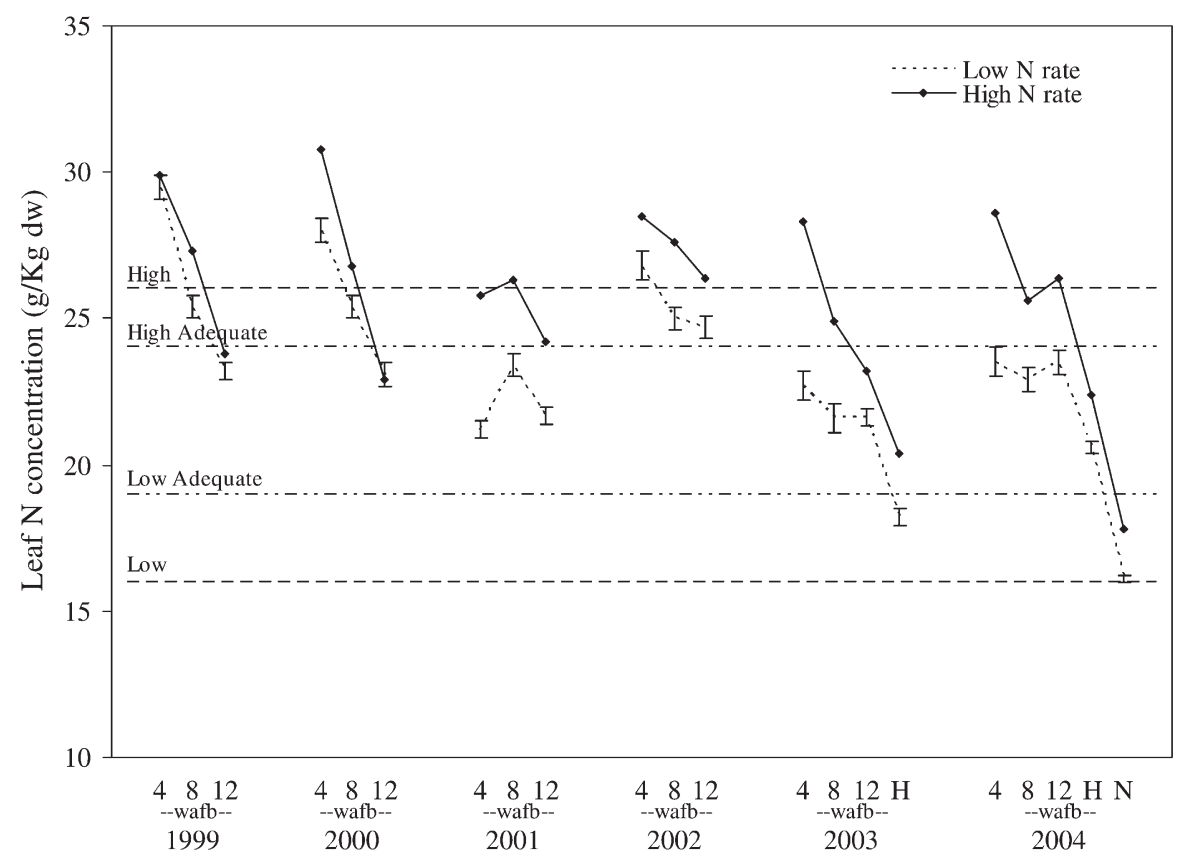

Fig. 1. Average leaf nitrogen $(\mathrm{N})$ concentration for low and high $\mathrm{N}$ rate for the Fuji apple cultivar throughout the growing season, 1999 to 2004. Samples collected 4, 8, and 12 weeks after full bloom (wafb) of 'Ambrosia' and at harvest (H) in 2003 to 2004 and November (N) in 2004. sEs for each date indicated on the low $\mathrm{N}$ treatment. Recommended local midsummer leaf $\mathrm{N}$ ranges appear as dotted horizontal lines.

2001 and an interaction between $\mathrm{N}$ timing and rate in 2004 (Table 4). Fruit N concentration was higher at high $\mathrm{N}$ for all cultivars in 2000 and 2001 and especially for 'Silken'. In 2004, fruit $\mathrm{N}$ concentration was higher at high $\mathrm{N}$ at all times, although fruit $\mathrm{N}$ concentration at low $\mathrm{N}$ was at a higher value for the 4 to 8 wafb treatment. Timing of $\mathrm{N}$ application

effects on fruit $\mathrm{N}$ concentration were not as consistent as the effects of $\mathrm{N}$ rate, occurring in 2000 and 2003, exhibiting an interaction with cultivar in 2001 and with rate in 2004. However, when significant, fruit $\mathrm{N}$ concentration was similar and highest after lateseason $\mathrm{N}$ applications (4 to 8 and 8 to 12 wafb) except for 'Fuji' and 'Silken' in 2001

Table 4. Harvest fruit nitrogen $(\mathrm{N})$ concentration as affected by rate and timing of fertigated $\mathrm{N}$ for Ambrosia, Cameo, Fuji, Gala, and Silken apple cultivars, 1999 to 2004.

\begin{tabular}{|c|c|c|c|c|c|c|c|c|c|c|c|}
\hline \multirow[b]{2}{*}{ Year } & \multicolumn{11}{|c|}{ Fruit $\mathrm{N}$ concn $\left(\mathrm{mg} \cdot \mathrm{kg}^{-1}\right.$ fresh weight) } \\
\hline & 1999 & 2000 & \multicolumn{4}{|c|}{2001} & 2002 & 2003 & \multicolumn{3}{|c|}{2004} \\
\hline \multicolumn{12}{|l|}{ Factor } \\
\hline $\mathrm{N}$ rate $(\mathrm{R})^{\mathrm{z}}$ & & & & & & & & & $0-4^{y}$ & $4-8$ & $8-12$ \\
\hline Low (L) & 503 & & & & & & 428 & 478 & 341 & 437 & 399 \\
\hline $\operatorname{High}(\mathrm{H})$ & 556 & & & & & & 482 & 523 & 457 & 500 & 490 \\
\hline Significance & $* * *$ & & & & & & $* * *$ & $* *$ & & $\mathrm{SE}=9$ & \\
\hline $\mathrm{N}$ timing $(\mathrm{T})^{\mathrm{y}}$ & & & $\mathrm{A}$ & $\mathrm{F}$ & $\mathrm{G}$ & $\mathrm{S}$ & & & & & \\
\hline 0 to 4 wafb & $496 \mathrm{~b}$ & 360 & 377 & 434 & 377 & 479 & $424 \mathrm{~b}$ & 476 & & & \\
\hline 4 to 8 wafb & $546 \mathrm{a}$ & 368 & 431 & 456 & 427 & 587 & $464 \mathrm{a}$ & 506 & & & \\
\hline 8 to 12 wafb & $540 \mathrm{a}$ & 359 & 424 & 431 & 446 & 519 & $476 \mathrm{a}$ & 510 & & & \\
\hline Significance & $* * *$ & NS & & $\mathrm{SE}=12$ & & & $* * *$ & NS & & & \\
\hline $\mathrm{R} \times \mathrm{T}$ interaction & NS & NS & & NS & & & NS & NS & & $*$ & \\
\hline Cultivar (CV) & & $\mathrm{L} \quad \mathrm{H}$ & $\mathrm{L}$ & & $\mathrm{H}$ & $\mathrm{H}$ & & & & & \\
\hline Ambrosia (A) & $505 \mathrm{~b}$ & $375 \quad 408$ & 393 & & 42 & & $435 \mathrm{c}$ & $412 \mathrm{c}$ & & $391 \mathrm{~d}$ & \\
\hline Cameo (C) & $514 \mathrm{~b}$ & $335 \quad 363$ & 361 & & 43 & & $429 \mathrm{c}$ & $521 \mathrm{ab}$ & & $422 \mathrm{c}$ & \\
\hline Fuji (F) & $\mathrm{nh}^{\mathrm{w}}$ & $367 \quad 422$ & 417 & & 46 & & $459 \mathrm{~b}$ & $513 \mathrm{~b}$ & & $453 \mathrm{~b}$ & \\
\hline Gala (G) & $521 \mathrm{~b}$ & $318 \quad 371$ & 399 & & 43 & & $460 \mathrm{~b}$ & $498 \mathrm{~b}$ & & $478 \mathrm{a}$ & \\
\hline Silken (S) & $566 \mathrm{a}$ & $300 \quad 380$ & 476 & & 58 & 30 & $490 \mathrm{a}$ & $552 \mathrm{a}$ & & $445 \mathrm{~b}$ & \\
\hline Significance & $* * *$ & $\mathrm{SE}^{\mathrm{x}}=9$ & & $\mathrm{SE}=10$ & & & $* * *$ & $* * *$ & & $* * *$ & \\
\hline $\mathrm{R} \times \mathrm{CV}$ & NS & $*$ & & $* *$ & & & NS & NS & & NS & \\
\hline $\mathrm{T} \times \mathrm{CV}$ & NS & NS & & $* *$ & & & NS & NS & & NS & \\
\hline Grand mean & 527 & 363 & & 437 & & & 455 & 497 & & 438 & \\
\hline
\end{tabular}

${ }^{\mathrm{z}}$ Fertigated at either $28 \mathrm{mg} \mathrm{N} / \mathrm{L}$ (low) or $168 \mathrm{mg} \mathrm{N} / \mathrm{L}$ (high) as calcium nitrate $(15.5 \mathrm{~N}-0 \mathrm{P}-0 \mathrm{~K})$.

${ }^{y}$ Applied weeks after full bloom (wafb) based on bloom date of 'Ambrosia'.

${ }^{\mathrm{x}}$ When interaction significant, SE of the interaction indicated.

"Not harvested (nh).

*,**,**Means significantly different at $P=0.05,0.01,0.001$, respectively, or nonsignificantly (Ns) different. and for low $\mathrm{N}$ rate in 2004. For these exceptions, fruit $\mathrm{N}$ concentration was higher in fruit receiving $\mathrm{N} 4$ to 8 wafb rather than 8 to 12 wafb. Fruit $\mathrm{N}$ concentration was generally lowest for fruit receiving $\mathrm{N}$ in the 4 weeks immediately after bloom. Cultivar effects were apparent each year, but the ranking from highest to lowest was not always consistent, although 'Silken' generally had high fruit $\mathrm{N}$ and smallest apples and 'Ambrosia' low $\mathrm{N}$ and medium-sized apples.

Fruit $\mathrm{N}$ concentration was more responsive to rate of $\mathrm{N}$ applied than leaf $\mathrm{N}$ concentration with the percentage annual increase from the low to high $\mathrm{N}$ treatment ranging from $9 \%$ to $24 \%$. Application of fertigated $\mathrm{N}$ from 4 to 12 wafb was more effective at increasing fruit $\mathrm{N}$ concentrations than $\mathrm{N}$ applications immediately postbloom, consistent with previous research that indicated early-season fruit growth, immediately postbloom, is partially supported by remobilized $\mathrm{N}$, whereas root-supplied $\mathrm{N}$ is important after this period, when fruits begin to size (Guak et al., 2003; Neilsen et al., 2006). Thus, unlike leaf $\mathrm{N}$ concentration, $\mathrm{N}$ fertigation later in the growing season would be more effective at increasing fruit $\mathrm{N}$ concentration.

Recommended fruit $\mathrm{N}$ concentrations are less well established than leaf values in many fruit-growing regions (Neilsen and Neilsen, 2003). In British Columbia, optimum values have been developed for the Ambrosia cultivar and range from 380 to $440 \mathrm{mg} \cdot \mathrm{kg}^{-1}$ (BCMAL, 2007). Average annual fruit $\mathrm{N}$ concentrations were within the desired range with the exception of lowest crop years in 1999 and 2003. This implies crop load is an important factor in fruit $\mathrm{N}$ concentration with low crop trees sensitive to accumulating higher fruit $\mathrm{N}$ concentration for a given $\mathrm{N}$ fertilization regime. The important role of crop load in affecting leaf and fruit $\mathrm{N}$ concentrations has been previously identified by Hansen (1980). Furthermore, our study indicated high $\mathrm{N}$ rate, $\mathrm{N}$ fertigation 4 to $12 \mathrm{wafb}$ as well as cultivar (e.g., 'Silken') are important factors that can increase fruit $\mathrm{N}$ concentration above the optimum range. It is well known commercially that high $\mathrm{N}$ applications can adversely affect fruit quality and increase harvest and storage disorders. It was not possible to assess fruit $\mathrm{N}$ concentration from this viewpoint because there were few fruit harvest disorders associated with harvested fruit and there was no systematic assessment of fruit storage disorders in our study. Future research should focus on fruit storability related to fruit $\mathrm{N}$ status because this relationship can be an important consideration in developing an appropriate fertigation strategy. In a wide-ranging study of 270 orchard-years $(3$ years $\times 3$ cultivars $\times 30$ orchards each) in southern interior British Columbia using traditional apple cultivars McIntosh, Spartan, and Golden Delicious, large fruit size, low fruit calcium (Ca) concentration, and high fruit $\mathrm{K} / \mathrm{Ca}$ ratios were the factors most correlated with increased fruit storage disorders, whereas correlations with fruit $\mathrm{N}$ concentration were rarely significant 
or consistent from year to year (Wolk et al., 1998).

Yield. Significant effects on yield in each season were, in general, associated with $\mathrm{N}$ rate and cultivar (data not shown). In 2001, yield across all cultivars was $14.4 \%$ higher as $\mathrm{N}$ application increased from low to high rate. This reflected greater fruit number rather than any change in average fruit size. Fruit number was also higher at high $\mathrm{N}$ rate in 2002 (data not shown). However, when considered over the first six (1999 to 2004) growing seasons, neither fruit number $(P=$ $0.09)$ nor yield $(P=0.10)$ was significantly affected by changing $\mathrm{N}$ rate (Table 5 ). The timing of $\mathrm{N}$ fertigation had no consistent effects on fruit yield, average fruit number, or fruit size annually (data not shown). Yield efficiency was unaffected by $\mathrm{N}$ treatments.

Yield and its components, fruit number and average fruit size, were affected by cultivar each year (data not shown). Over the first six growing seasons, yield differences among cultivars were much greater than those between $\mathrm{N}$ rate and timing (Table 5). For example, yield more than doubled between the lowest ('Ambrosia') and highest ('Silken') -yielding cultivars. 'Ambrosia' had the lowest cumulative fruit number combined with medium overall fruit size (Table 5). Cumulative yield efficiency was among the highest value for 'Ambrosia', implying fruit production was achieved on smaller trees. 'Silken' had the greatest fruit numbers, smallest fruit size, and intermediate yield efficiency (Table 5). 'Cameo' had the second highest cumulative yield, largest fruit, and yield efficiency similar to 'Ambrosia'. 'Fuji' produced intermediate yield, fruit size, and fruit numbers but produced the crop on larger trees, resulting in lowest yield effi- ciency. The relatively low yield of 'Gala' was a reflection of smaller fruit size (Table 5).

Increased yield associated with higher rates of $\mathrm{N}$ has historically been a frequently reported consequence when $\mathrm{N}$ is limiting production (Oberly and Boynton, 1966). In the single year of yield response across all cultivars (2001), it was not possible to directly relate yield response to exceeding a leaf $\mathrm{N}$ threshold, because greater leaf $\mathrm{N}$ increases and higher concentrations were achieved in other years when yield was unaffected by N. Over the long term, cumulative yield patterns suggested differences in cultivar response to N. With respect to long-term yield, $\mathrm{N}$ values were highest in the order 'Silken' > 'Cameo' $>$ 'Fuji' $>$ 'Gala' > 'Ambrosia'. 'Silken', with the highest overall yield and high yield efficiency, had smallest average fruit size (168 g). Average fruit size was also less than $200 \mathrm{~g}$ for ' $\mathrm{Gala}$ ' $(184 \mathrm{~g})$ and 'Cameo' (188 g), the two cultivars with the lowest cumulative yield. The lack of fruit size response of cultivars to $\mathrm{N}$ rate and timing suggest manipulation of crop load rather than $\mathrm{N}$ fertilization would be a more effective strategy for improving fruit size of cultivars having small fruit. In this regard, the strategy of thinning all cultivars to the same spacing, like used in our study, should be adjusted to allow more aggressive thinning of smaller-fruited apples. The insensitivity of 'Gala' fruit quality, including size, to variation in rate and timing of broadcast $\mathrm{N}$ applications has also previously been observed in a study involving this cultivar (Neilsen et al., 1999a). 'Cameo' was able to maintain the largest fruit size (212 g), highest yield efficiency, and high cumulative yield despite overall lowest midsummer leaf $\mathrm{N}$ concentrations. 'Fuji' was capable of achieving good cumulative yield and fruit size and high leaf $\mathrm{N}$ concentration

Table 5. Cumulative yield, fruit number, average fruit weight, and yield efficiency as affected by rate and timing of fertigated nitrogen $(\mathrm{N})$ for Ambrosia, Cameo, Fuji, Gala, and Silken apple cultivars, 1999 to 2004.

\begin{tabular}{|c|c|c|c|c|}
\hline Factor & $\begin{array}{c}\text { Cumulative yield } \\
(\mathrm{kg} / \text { tree })\end{array}$ & $\begin{array}{c}\text { Fruit number } \\
(\mathrm{n} / \text { tree })\end{array}$ & Avg fruit wt $(g)$ & $\begin{array}{l}\text { Yield efficiency } \\
\left(\mathrm{kg} / \mathrm{cm}^{2} \mathrm{TCSA}^{\mathrm{x}}\right)\end{array}$ \\
\hline \multicolumn{5}{|l|}{$\overline{\mathrm{N}}$ rate $(\mathrm{R})^{\mathrm{z}}$} \\
\hline Low (L) & 52.6 & 277 & 191 & 3.48 \\
\hline $\operatorname{High}(\mathrm{H})$ & 55.8 & 292 & 193 & 3.43 \\
\hline Significance & NS & NS & NS & NS \\
\hline \multicolumn{5}{|l|}{$\mathrm{N}$ timing $(\mathrm{T})^{\mathrm{y}}$} \\
\hline 0 to 4 wafb & 53.5 & 278 & 194 & 3.45 \\
\hline 4 to 8 wafb & 54.2 & 285 & 190 & 3.46 \\
\hline 8 to 12 wafb & 54.0 & 288 & 189 & 3.39 \\
\hline Significance & NS & NS & NS & NS \\
\hline $\mathrm{R} \times \mathrm{T}$ interaction & NS & NS & NS & NS \\
\hline \multicolumn{5}{|l|}{ Cultivar (CV) } \\
\hline Ambrosia & $42.7 \mathrm{e}$ & $227 \mathrm{c}$ & $188 \mathrm{c}$ & $3.78 \mathrm{a}$ \\
\hline Cameo & $59.3 \mathrm{~b}$ & $279 \mathrm{~b}$ & $212 \mathrm{a}$ & $3.84 \mathrm{a}$ \\
\hline Fuji & $56.7 \mathrm{c}$ & $268 \mathrm{~b}$ & $204 \mathrm{~b}$ & $2.91 \mathrm{c}$ \\
\hline Gala & $48.5 \mathrm{~d}$ & $262 \mathrm{~b}$ & $184 \mathrm{~d}$ & $3.22 \mathrm{~b}$ \\
\hline Silken & $64.2 \mathrm{a}$ & $383 \mathrm{a}$ & $168 \mathrm{e}$ & $3.42 \mathrm{~b}$ \\
\hline Significance & $* * *$ & $* * *$ & $* * *$ & $* * *$ \\
\hline $\mathrm{R} \times \mathrm{CV}$ & NS & NS & NS & NS \\
\hline $\mathrm{T} \times \mathrm{CV}$ & NS & NS & NS & NS \\
\hline $\mathrm{R} \times \mathrm{T} \times \mathrm{CV}$ & NS & NS & NS & NS \\
\hline Grand mean & 53.9 & 284 & 191 & 3.43 \\
\hline
\end{tabular}

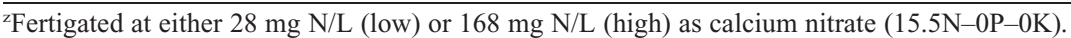

${ }^{y}$ Applied weeks after full bloom (wafb) based on bloom date of 'Ambrosia'.

${ }^{\mathrm{x}}$ Trunk cross-sectional area (TCSA) as measured $0.3 \mathrm{~m}$ above the graft union.

***Means significantly different at $P=0.001$ or nonsignificantly (NS) different. (averaging $25 \mathrm{~g} \cdot \mathrm{kg}^{-1}$ over 6 years) and good fruit size over the tested $\mathrm{N}$ rates despite having the lowest yield efficiency.

It is also noteworthy that timing of $\mathrm{N}$ availability, specifically summer $\mathrm{N}$ applications, which enhanced flowering and fruit set in earlier pot studies (Hill-Cottingham and Williams, 1967), did not affect yield. This supports previous fertigation timing research on 'Gala' (Neilsen et al., 2000) and suggests the timing of fertigated $\mathrm{N}$ application should be based on criteria other than maximization of yield.

Fruit quality. Fruit firmness (Table 6) and percent red color at harvest (Table 7) were most affected by $\mathrm{N}$ treatments. The other standard quality characteristics of harvest fruit, including SSC and TA, were not significantly affected by $\mathrm{N}$ treatments (data not shown).

The effects of $\mathrm{N}$ treatments on fruit firmness were consistent throughout the study (Table 6). High $\mathrm{N}$ reduced fruit firmness for every year, except first crop, in 1999. Treatment differences occurred across all cultivars, except in 2001 (significant rate $\times$ cultivar interaction), when firmness was lower for high $\mathrm{N}$ treatments for all, except 'Ambrosia'. In contrast, fruit firmness was not different among $\mathrm{N}$ timing treatments throughout the study. Like with most measured plant parameters, fruit firmness was affected by cultivar every year (Table 6). Although the cultivar ranking with respect to firmness was not consistent from year to year, 'Fuji' and 'Gala' generally had the firmest fruit.

Fertigated applications of the higher $\mathrm{N}$ rate could decrease percent red color of the four red-skinned apple cultivars (Table 7). Differences were statistically significant in the 3 years of highest crop load (2001, 2002, and 2004). However, in 2004, there was a significant interaction between rate and timing of $\mathrm{N}$ application because reduced red color at high $\mathrm{N}$ rate was measured for fruit fertigated early ( 0 to $4 \mathrm{wafb}$ ) or late ( 8 to $12 \mathrm{wafb}$ ) but not midseason ( 4 to 8 wafb). Generally red color was unaffected by timing of $\mathrm{N}$ application, except for the aforementioned 2004 season, when red color was very high for apples fertigated within 4 weeks of bloom at the low $\mathrm{N}$ rate (Table 7). Like with the other parameters measured, cultivar consistently affected percent red color with highest annual values for either 'Gala' or 'Cameo', whereas 'Fuji' always had among the lowest red color.

Reductions in fruit firmness and red coloration were the most sensitive apple quality indicators of plant $\mathrm{N}$ response in this study. $\mathrm{N}$ oversupply has frequently been associated with reduced fruit firmness and inhibition of red color development (Neilsen and Neilsen, 2003). The prominence of reduced firmness at high $\mathrm{N}$ in this fertigation experiment contrasts with more ambiguous links between high $\mathrm{N}$ and firmness in studies comparing various broadcast $\mathrm{N}$ application rates on widely spaced, vigorous trees (Oberly and Boynton, 1966). This implies reduced fruit firmness may be a sensitive indicator of $\mathrm{N}$ oversupply in fertigated, high-density 
Table 6. Fruit firmness at harvest as affected by rate and timing of fertigated nitrogen $(\mathrm{N})$ for Ambrosia, Cameo, Fuji, Gala, and Silken apple cultivars, 1999 to 2004.

\begin{tabular}{|c|c|c|c|c|c|c|c|}
\hline \multirow[b]{2}{*}{ Year } & \multicolumn{7}{|c|}{ Fruit firmness $(\mathrm{N})$} \\
\hline & 1999 & 2000 & \multicolumn{2}{|c|}{2001} & 2002 & 2003 & 2004 \\
\hline \multicolumn{8}{|l|}{ Factor } \\
\hline \multicolumn{8}{|l|}{$\mathrm{N}$ rate $(\mathrm{R})^{\mathrm{z}}$} \\
\hline Low (L) & 85.7 & 82.4 & & & 80.9 & 89.9 & 84.7 \\
\hline High $(\mathrm{H})$ & 84.7 & 80.9 & & & 78.7 & 87.3 & 81.4 \\
\hline Significance & NS & $*$ & & & $* * *$ & $* * *$ & $* * *$ \\
\hline \multicolumn{8}{|l|}{$\mathrm{N}$ timing $(\mathrm{T})^{\mathrm{y}}$} \\
\hline 0 to 4 wafb & 84.8 & 81.1 & \multicolumn{2}{|c|}{81.5} & 80.2 & 87.8 & 83.6 \\
\hline 4 to $8 \mathrm{wafb}$ & 84.7 & 82.1 & \multicolumn{2}{|c|}{82.7} & 79.7 & 89.1 & 84.0 \\
\hline 8 to 12 wafb & 85.5 & 81.6 & \multicolumn{2}{|c|}{82.6} & 79.8 & 89.4 & 82.1 \\
\hline Significance & NS & NS & \multicolumn{2}{|c|}{ NS } & NS & NS & NS \\
\hline \multirow[t]{2}{*}{$\mathrm{R} \times \mathrm{T}$ interaction } & NS & NS & \multicolumn{2}{|c|}{ NS } & NS & NS & NS \\
\hline & & & $\mathrm{L}$ & $\mathrm{H}$ & & & \\
\hline \multicolumn{8}{|l|}{ Cultivar } \\
\hline Ambrosia & $89.2 \mathrm{a}$ & $85.0 \mathrm{~b}$ & 77.5 & 77.2 & $79.2 \mathrm{c}$ & $86.1 \mathrm{bc}$ & $87.5 \mathrm{a}$ \\
\hline Cameo & $82.5 \mathrm{~b}$ & $80.7 \mathrm{c}$ & 82.6 & 80.1 & $78.0 \mathrm{c}$ & $84.6 \mathrm{c}$ & $79.2 \mathrm{~b}$ \\
\hline Fuji & $\mathrm{nh}^{\mathrm{w}}$ & $89.2 \mathrm{a}$ & 92.8 & 87.2 & $81.0 \mathrm{~b}$ & $93.1 \mathrm{a}$ & $88.5 \mathrm{a}$ \\
\hline Gala & $89.7 \mathrm{a}$ & $85.0 \mathrm{~b}$ & 83.1 & 80.4 & $87.5 \mathrm{a}$ & $92.5 \mathrm{a}$ & $86.9 \mathrm{a}$ \\
\hline Silken & $79.2 \mathrm{c}$ & $68.2 \mathrm{~d}$ & 83.0 & 78.2 & $73.5 \mathrm{~d}$ & $87.1 \mathrm{~b}$ & $73.4 \mathrm{c}$ \\
\hline Significance & $* * *$ & $* * *$ & \multicolumn{2}{|c|}{$\mathrm{SE}^{\mathrm{x}}=0.8$} & $* * *$ & $* * *$ & $* * *$ \\
\hline $\mathrm{R} \times \mathrm{CV}$ & NS & NS & \multicolumn{2}{|c|}{$*$} & NS & NS & NS \\
\hline $\mathrm{T} \times \mathrm{CV}$ & NS & NS & \multicolumn{2}{|c|}{ NS } & NS & NS & NS \\
\hline $\mathrm{R} \times \mathrm{T} \times \mathrm{CV}$ & NS & NS & \multicolumn{2}{|c|}{ NS } & NS & NS & NS \\
\hline Grand mean & 85.0 & 81.6 & \multicolumn{2}{|c|}{82.3} & 79.9 & 88.8 & 83.2 \\
\hline
\end{tabular}

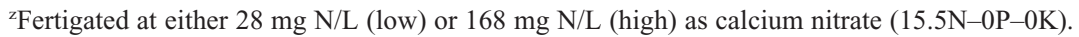

y Applied weeks after full bloom (wafb) based on bloom date of 'Ambrosia'.

${ }^{\mathrm{x}}$ When interaction significant, SE of the interaction indicated.

${ }^{w}$ Not harvested (nh).

****Means significantly different at $P=0.05,0.001$, respectively, or nonsignificantly (Ns) different.

Table 7. Red color at harvest as affected by rate and timing of fertigated nitrogen (N) for Ambrosia, Cameo, Fuji, and Gala apple cultivars, 1999 to 2004.

\begin{tabular}{|c|c|c|c|c|c|c|c|}
\hline \multirow[b]{2}{*}{ Year } & \multicolumn{7}{|c|}{ Red color ( $\%$ solid red $)$} \\
\hline & 1999 & 2000 & 2001 & 2002 & 2003 & \multicolumn{2}{|c|}{2004} \\
\hline \multicolumn{8}{|l|}{ Factor } \\
\hline \multicolumn{8}{|l|}{$\mathrm{N}$ rate $(\mathrm{R})^{\mathrm{z}}$} \\
\hline Low (L) & 85 & 80 & 80 & 85 & 85 & & \\
\hline High $(\mathrm{H})$ & 80 & 80 & 75 & 80 & 80 & & \\
\hline Significance & NS & NS & $*$ & $*$ & NS & & \\
\hline $\mathrm{N}$ timing $(\mathrm{T})^{\mathrm{y}}$ & & & & & & $\mathrm{L}$ & $\mathrm{H}$ \\
\hline 0 to $4 \mathrm{wafb}$ & 80 & 80 & 80 & 85 & 80 & 90 & 80 \\
\hline 4 to $8 \mathrm{wafb}$ & 85 & 80 & 80 & 80 & 85 & 75 & 75 \\
\hline 8 to 12 wafb & 80 & 80 & 80 & 80 & 85 & 80 & 75 \\
\hline Significance & NS & NS & NS & NS & NS & \multicolumn{2}{|c|}{$\mathrm{SE}^{\mathrm{x}}=1.9$} \\
\hline $\mathrm{R} \times \mathrm{T}$ interaction & NS & NS & NS & NS & NS & & \\
\hline \multicolumn{8}{|l|}{ Cultivar } \\
\hline Ambrosia & $75 \mathrm{~b}$ & $75 \mathrm{c}$ & $70 \mathrm{c}$ & $80 \mathrm{~b}$ & $80 \mathrm{~b}$ & & \\
\hline Cameo & $85 \mathrm{a}$ & $85 \mathrm{~b}$ & $80 \mathrm{~b}$ & $90 \mathrm{a}$ & $90 \mathrm{a}$ & & \\
\hline Fuji & $\mathrm{nh}^{\mathrm{w}}$ & $75 \mathrm{c}$ & $70 \mathrm{c}$ & $65 \mathrm{c}$ & $75 \mathrm{c}$ & & \\
\hline Gala & $85 \mathrm{a}$ & $90 \mathrm{a}$ & $95 \mathrm{a}$ & $95 \mathrm{a}$ & $85 \mathrm{ab}$ & & \\
\hline Significance & $* * *$ & $* * *$ & $* * *$ & $* * *$ & $* * *$ & & \\
\hline $\mathrm{R} \times \mathrm{CV}$ & NS & NS & NS & NS & NS & & \\
\hline $\mathrm{T} \times \mathrm{CV}$ & NS & NS & NS & NS & NS & & \\
\hline $\mathrm{R} \times \mathrm{T} \times \mathrm{CV}$ & NS & NS & NS & NS & NS & & \\
\hline Grand mean & 80 & 80 & 80 & 80 & 85 & & \\
\hline
\end{tabular}

${ }^{\mathrm{z}}$ Fertigated at either $28 \mathrm{mg} \mathrm{N} / \mathrm{L}$ (low) or $168 \mathrm{mg} \mathrm{N} / \mathrm{L}$ (high) as calcium nitrate $(15.5 \mathrm{~N}-0 \mathrm{P}-0 \mathrm{~K})$.

${ }^{y}$ Applied weeks after full bloom (wafb) based on bloom date of 'Ambrosia'.

${ }^{\mathrm{x}}$ When interaction significant, SE of the interaction indicated.

wNot harvested (nh).

****Means significantly different at $P=0.05,0.001$, respectively, or nonsignificantly (Ns) different.

orchards on dwarfing rootstocks. In contrast, reduced red color at harvest, resulting from high $\mathrm{N}$, was observed less frequently and usually when crop load was large, indicating its usefulness as a $\mathrm{N}$ indicator in high crop years. The general lack of effect of $\mathrm{N}$ timing on the important fruit quality characteristics of firmness and percent red color suggest a potential for flexibility in $\mathrm{N}$ timing with respect to these quality parameters over the development is a major limitation to production of quality 'Fuji' apples at this site and would be exacerbated by additional $\mathrm{N}$ applications. In contrast, 'Gala' produced firm and highly colored fruit regardless of $\mathrm{N}$ regime. 'Cameo', which had good potential for yield response to additional $\mathrm{N}$, had red but softer fruit, suggesting that reductions in firmness rather than fruit color may be an obstacle for establishing a higher $\mathrm{N}$ fertilization regime for this cultivar.

\section{Conclusions}

Increasing the amount of $\mathrm{N}$ fertigated within the 12-week period after bloom consistently increased midsummer leaf $\mathrm{N}$ concentration and especially harvest fruit $\mathrm{N}$ concentration for five different apple cultivars ranging in harvest maturity from early September to late October. The low and high $\mathrm{N}$ treatments were maintained by adjusting daily $\mathrm{N}$ applications to create contrasting soil solution $\mathrm{NO}_{3}-\mathrm{N}$ concentrations. This resulted in application rates approximating $25 \mathrm{~kg} \mathrm{~N} /$ ha/year at low $\mathrm{N}$ and $125 \mathrm{~kg} \mathrm{~N} / \mathrm{ha} /$ year at high $\mathrm{N}$, both conservative amounts compared with many commercial application rates. The high $\mathrm{N}$ rate was associated with fruit quality decline, including decreases in fruit firmness and, at high crop load, reductions in percent red color. In contrast, cumulative yield was unaffected by $\mathrm{N}$ rate. Thus, optimum fruit quality and adequate $\mathrm{N}$ availability would be achievable by maintaining fertigation concentrations at the $42 \mathrm{mg} \cdot \mathrm{L}^{-1}$ concentration recommended by Israeli researchers (Bar-Yosef et al.,1988) or by applying $40 \mathrm{~kg}$ $\mathrm{N} /$ ha by daily applications over a minimum of a 4-week period during the main growing season.

The major consequence of varying the timing of $\mathrm{N}$ application from early to late in the 12 wafb period was on tissue $\mathrm{N}$ concentration. Fruit $\mathrm{N}$ concentration was most effectively increased by $\mathrm{N}$ fertigation either 4 to 8 or 8 to 12 wafb. Standard (midsummer) leaf $\mathrm{N}$ concentrations were most increased by $\mathrm{N}$ applications in the 4-week period immediately preceding leaf sampling. However, leaf $\mathrm{N}$ concentrations could be increased at any time during the 12-week period by 4 weeks of fertigation. Annually, there was a steady decline in leaf $\mathrm{N}$ concentrations postbloom with minimum leaf $\mathrm{N}$ concentrations observed at harvest or postharvest. Altering the timing of $\mathrm{N}$ application within the 12week period had minimal effects on yield, fruit flesh firmness, and red color. Thus, from a production viewpoint, rate is more important than time of $\mathrm{N}$ application. Low leaf $\mathrm{N}$ concentration could be increased by fertigating at any time within 12 weeks of bloom without adversely affecting yield or quality of harvested fruit. In practice, avoiding the 4 weeks immediately after bloom would be desirable because leaf $\mathrm{N}$ concentrations are often high at this time and growth sustained by remobilized N. Furthermore, the minimum leaf $\mathrm{N}$ concentrations observed for all cultivars around harvest time (beyond the 
12-week period tested here) suggest very late season fertigation should be researched to assess benefits and possible detrimental effects on winterhardiness.

The variation in performance of the five different apple cultivars under relatively uniform conditions, including exposure to the same range of $\mathrm{N}$ rate and timing treatments on the same rootstock, while growing on the same soil series and site, supports the importance of tailoring $\mathrm{N}$ fertilization strategies to cultivar. For example, both 'Gala' and 'Silken' generally had firm fruit with good red color (for 'Gala') but small size suggesting crop load reduction to increase fruit size would be more important than increasing $\mathrm{N}$ rate. The issue of most interest for the Ambrosia cultivar would be whether management strategies could be developed to counteract a tendency for low fruit numbers and for 'Cameo' to overcome a tendency for soft fruit. Despite the possibility of good yield, firm fruit and high leaf $\mathrm{N}$ concentration for 'Fuji', low fruit red color was a major fruit quality concern regardless of $\mathrm{N}$ regime.

\section{Literature Cited}

Bar-Yosef, B., S. Schwartz, T. Markovich, B. Lucas, and R. Assaf. 1988. Effect of root volume and nitrate solution concentration on growth, fruit yield, and temporal $\mathrm{N}$ and water uptake rates by apple trees. Plant Soil 107:49-56.

British Columbia Ministry of Agriculture and Lands (BCMAL). 2007. Integrated fruit production guide for commercial fruit growers. Interior Districts, Victoria, BC, Canada.

Cheng, L., S. Dong, and L.H. Fuchigami. 2002. Uptake and nitrogen mobilization by apple leaves in relation to tree nitrogen status in autumn. J. Hort. Sci. Biotechnol. 77:13-18.

Guak, S., D. Neilsen, P. Millard, R. Wendler, and G.H. Neilsen. 2003. Determining the role of N remobilization for growth of apple (Malus domestica Borkh.) trees by measuring xylemsap N flux. J. Expt. Bot. 54:2121-2131.

Hansen, P. 1980. Crop load and nutrient translocation, p. 201-212. In: Atkinson, D., J.E. Jackson, R.O. Sharples, and W.M. Waller (eds.). Mineral nutrition of fruit trees. Butterworths, London, UK.

Haynes, R.J. 1985. Principles of fertiliser use for trickle irrigated crops. Fert. Res. 6:235-255.
Hill-Cottingham, D.G. and R.R. Williams. 1967. Effect of time of application of fertilizer nitrogen on the growth, flower development and fruit set of maiden apple trees, var. Lord Lambourne, and on the distribution of total nitrogen within the trees. J. Hort. Sci. 42:319338.

Malaguti, D., P. Millard, R. Wendler, A. Hepburn, and M. Tagliavini. 2001. Translocation of amino acids in the xylem of apple (Malus domestica Borkh.) trees in spring as a consequence of both $\mathrm{N}$ remobilization and root uptake. J. Expt. Bot. 52:1665-1671.

Millard, P. and G.H. Neilsen. 1989. The influence of nitrogen supply on the uptake and remobilization of stored $\mathrm{N}$ for the seasonal growth of apple trees. Ann. Bot. (Lond.) 63:301-309.

Neilsen, D., P. Millard, L.C. Herbert, G.H. Neilsen, E.J. Hogue, P. Parchomchuk, and B.J. Zebarth. 2001a. Remobilization and uptake of $\mathrm{N}$ by newly planted apple (Malus domestica) trees in response to irrigation method and timing of $\mathrm{N}$ application. Tree Physiol. 21:513-521.

Neilsen, D., P. Millard, G.H. Neilsen, and E.J. Hogue. 2001b. Nitrogen uptake, efficiency of use, and partitioning for growth in young apple trees. J. Amer. Soc. Hort. Sci. 126:144-150.

Neilsen, D. and G.H. Neilsen. 2002. Efficient use of nitrogen and water in high-density apple orchards. HortTechnology 12:19-25.

Neilsen, D., G.H. Neilsen, and J.W. Hall. 2000 Fruit mineral concentration and quality of 'Gala' apples as affected by rate and timing of fertigated N. Acta Hort. 512:159-167.

Neilsen, D., G.H. Neilsen, L. Herbert, P. Millard, and S. Guak. 2006. Allocation of dry matter and $\mathrm{N}$ to fruit and shoots in dwarf apple in response to sink size and $\mathrm{N}$ availability. Acta Hort. 721:33-40.

Neilsen, G.H., E.J. Hogue, and M. Meheriuk. 1999a. Nitrogen fertilization and orchard-floor vegetation management affect growth, nutrition and fruit quality of Gala apple. Can. J. Plant Sci. 79:379-385.

Neilsen, G.H., P.B. Hoyt, and D. Neilsen. 1995. Soil chemical changes associated with NPfertigated and drip irrigated high-density apple orchards. Can. J. Soil Sci. 75:307-310.

Neilsen, G.H. and D. Neilsen. 2003. Nutritional requirements of apple, p. 267-302. In: Ferree, D.C. and I.J. Warrington (eds.). Apples, production and uses. CABI Publishing, Oxon, UK.

Neilsen, G.H., D. Neilsen, and F. Peryea. 1999b. Response of soil and irrigated fruit trees to fertigation or broadcast application of nitrogen, phosphorus, and potassium. HortTechnology 9:393-401.

Neilsen, G.H., D. Neilsen, P. Toivonen, and L. Herbert. 2008. Annual bloom-time phosphorus fertigation affects soil phosphorus, apple tree phosphorus nutrition, yield and fruit quality. HortScience 43:885-890.

Oberly, G.H. and D. Boynton. 1966. Apple nutrition, p. 1-50. In: Childers, N.F. (ed.). Nutrition of fruit crops. Horticultural Publications, New Brunswick, NJ.

Parchomchuk, P., R.C. Berard, and T.W. Van der Gulik. 1996. Automatic irrigation scheduling using an electronic atmometer, p. 1099-1104. In: Camp, C.R., E.J. Sadler, and R.E. Yoder (eds.). Evapotranspiration and irrigation scheduling. Amer. Soc. Agr. Engn. Proc. Intl. Conf., San Antonio, TX.

Sanchez, E.E., H. Khemira, D. Sugar, and T.L. Righetti. 1995. Nitrogen management in orchards, p. 327-380. In: Bacon, P.E. (ed.). Nitrogen fertilization in the environment. Marcel Dekker, New York, NY.

SAS. 1989. SAS/STAT. User's guide. Vers. 6, Vol. 2. SAS Inst., Cary, NC.

Sweeney, R.A. and P.F. Rexroad. 1987. Comparison of LECO FP-228 'Nitrogen Determinator' with AOAC copper catalyst Kjeldahl method for crude protein. J. Assoc. Off. Anal. Chem. 70:1028-1030.

Tagliavini, M., D. Scudellari, B. Marangoni, and M. Tosselli. 1996. Nitrogen fertilization management in orchards to reconcile productivity and environmental aspects. Fert. Res. 43:93102.

Wassenaar, L.I., M.J. Hendry, and N. Harrington. 2006. Decadal geochemical and isotopic trends for nitrate in a transboundary aquifer and implications for beneficial agricultural management practices. Environ. Sci. Technol. 40:4626-4632.

Weinbaum, S.A., R.S. Johnson, and T.M. De Jong 1992. Causes and consequences of over fertilization in orchards. HortTechnology 2:112121.

Wittneben, U. 1986. Soils of the Okanagan and Similkameen Valleys. Ministry of Environment Technical Report 10. British Columbia Soil Survey, Report 52, Victoria, BC, Canada. Wolk, W.D., O.L. Lau, G.H. Neilsen, and B.G. Drought. 1998. Factors and time of sample collection for correlating storage potential of 'McIntosh', 'Spartan' and 'Golden Delicious' apples. J. Amer. Soc. Hort. Sci. 123:104 109. 